\title{
Kinetics of amino acid and glucose absorption following pancreatic diversion in the pig
}

\author{
BY A. RÉRAT AND R. CALMES \\ Departement NASA, CRJ-INRA, Domaine de Vilvert, Jouy-en-Josas 78352, France
}

AND T. CORRING AND P. VAISSADE

UEPSD, CRJ-INRA, Domaine de Vilvert, Jouy-en-Josas 78352, France

(Received 18 July 1994 - Revised 6 February 1995 - Accepted 25 May 1995)

\begin{abstract}
An experiment was conducted in the pig to determine the consequences of deprivation of exocrine pancreatic secretion on the composition and quantity of nutrients absorbed after intake of a balanced diet. Five growing pigs $(53.8 \mathrm{~kg}$ body weight) were fitted with permanent catheters in the portal vein and the carotid artery and with an electromagnetic flow probe around the portal vein to measure the exchanges between the blood and the intestinal lumen. They were also fitted with a permanent catheter in the duct of Wirsung to educe the exocrine pancreatic secretion and another one in the duodenum in order to reintroduce it. In each animal, glucose, amino- $\mathrm{N}$ and amino acid absorption as well as insulin and glucagon production were measured over a period of $10 \mathrm{~h}$ after the meal (semi-purified diet based on purified starch and containing $180 \mathrm{~g}$ fish meal $/ \mathrm{kg}$, DM content of the meal $731 \mathrm{~g}$ ), either in the presence of pancreatic juice (group C: immediate reintroduction), or in the absence of pancreatic juice (group D: deprivation). The deprivation of pancreatic juice provoked a marked depression in the absorption of glucose (D 67.9 (SEM 27.9) g/10 h, C 437.7 (SEM 39.5) g/10 h, P<0.001), and of amino-N (D 7.55 (SEM 0.54) $\mathrm{g} / 10 \mathrm{~h}, \mathrm{C} 15.80$ (SEM 0.79 ) $\mathrm{g} / 10 \mathrm{~h}, P<0.001$ ). The composition of the mixture of amino acids in the portal blood was only slightly modified: only the levels of histidine $(P<0.05)$ and of valine $(P<0.06, N S)$ decreased in the absence of pancreatic juice. Insulin production was much lower (by $64 \%, P<0.05$ ) in the absence of pancreatic juice whereas that of glucagon was not affected.
\end{abstract}

Pancreatic diversion: Glucose absorption: Amino acid absorption: Insulin secretion

The role of the exocrine pancreatic secretion in the digestion of feeds has been investigated in the past by either digestibility or absorption studies. Thus ligature of the pancreatic duct has been shown to decrease the apparent digestibility of protein between 13 and $70 \%$ in the pig (Pekas et al. 1964; Anderson \& Ash, 1971; Corring \& Bourdon, 1977) and about $28 \%$ in the rabbit (Corring \& Lebas, 1977). The absence of pancreatic enzymes in the gut due to discontinuous pancreatic deprivation resulted in an early depression of the portal appearance of amino- $\mathrm{N}$ and carbohydrate digestive products (Rérat et al. 1977). However, it is not possible from these studies to determine whether these quantitative changes in digestibility are associated with qualitative changes in the absorption of some nutrients such as amino acids or carbohydrates. It is known that pancreatic proteolytic enzymes cut specific peptide bonds between defined amino acids; thus, their deficiency may affect the release of amino acids present in the core of the peptide chains. Furthermore, these changes in digestion may alter the production of the various gastrointestinal and pancreatic regulatory peptides likely to be involved in general metabolism, such as insulin and glucagon.

The present experiment was conducted in unanaesthetized pigs to measure quantitative and qualitative changes in carbohydrate and amino acid absorption resulting from 
discontinuous pancreatic exocrine deprivation, and to determine the possible consequences of these changes on the secretion of two regulatory peptides, insulin and glucagon.

\section{EXPERIMENTAL}

\section{Animals}

Five castrated male Large White pigs (about $40 \mathrm{~kg}$ body weight), originating from the herd of the Nutrition Department of the Institut National de la Recherche Agronomique (INRA) were used. For 1 month before the experiment they received a well balanced diet (800-1000 g/meal according to appetite, Table 1) twice daily at 09.00 and 17.00 hours. The mean growth rate of the animals during this period was about $600 \mathrm{~g} / \mathrm{d}$. Each animal was anaesthetized and fitted with an electromagnetic flow probe around the portal vein for measuring the portal flow rate, and with two catheters, one in the left brachiocephalic artery through the carotid route, and the other in the portal vein by procedures described elsewhere (Rérat et al. 1980). The animals were also fitted with permanent pancreatic and duodenal cannulas (Corring et al. 1972) allowing diversion with or without reintroduction of the pancreatic juice. The animals, in whom the pancreatic juice was automatically recycled into the gut (Juste et al. 1983), began to eat $1-2 \mathrm{~d}$ after surgery and rapidly recovered their former growth rate. They were given penicillin $\left(1.2 \times 10^{6} \mathrm{IU} / \mathrm{d}\right)$ and streptomycin $(1 \mathrm{~g} / \mathrm{d})$ for $3 \mathrm{~d}$ after surgery. The catheters permitted painless blood sampling in conscious animals placed in restraining cages. Throughout their experimental life the animals were maintained according to principles of care of laboratory animals.

\section{Experimental design and measurements}

The experiment began 7-10 d after surgery, when the animals had recovered a normal appetite and growth rate. Each animal was subjected to two $10 \mathrm{~h}$ trials at 3-4 dintervals; during the recovery period between trials they were given the same diet (two meals daily under the same conditions as before surgery). Each trial started at 09.00 hours after a fasting period of $18 \mathrm{~h}$, the last evening meal being fed at 15.00 hours on the day before and the next one at 17.00 hours on the day of the trial. In one of the two trials pancreatic juice was reintroduced into the gut; in the other it was not. The size of the experimental meal $(800 \mathrm{~g}$, i.e. $731 \mathrm{~g} \mathrm{DM})$ was the same in both. In the trial with no reintroduction, return of the pancreatic juice was stopped $14 \mathrm{~h}$ before the experimental meal to make sure that no pancreatic enzymes were left in the gut; this was confirmed by enzymic determination in gut contents taken via the intestinal cannula (amylase (EC 3.2.1.1): Metais \& Bieth, 1968; chymotrypsin (EC 3.4.21.1) and trypsin (EC 3.4.21.4): Reboud et al. 1962). Blood was sampled ( $10 \mathrm{ml}$ by each route) at the meal time, every 15 min during the 1st hour, then every $30 \mathrm{~min}$ for $3 \mathrm{~h}$, and every $60 \mathrm{~min}$ until $10 \mathrm{~h}$ after the meal. Loss of blood was compensated by saline injection into the bloodstream, and the blood status was checked by packed cell volume measurements. Meanwhile, the portal flow rate was recorded continuously.

From one animal to the other, reintroduction of the pancreatic juice during the first trial was alternated with no reintroduction, to avoid interactions between treatments and time. At the time of the trials the mean body weight of the animals was 53.2 (SEM 2.8 ) $\mathrm{kg}$ for the trials without pancreatic deprivation and 54.4 (SEM 3.2) $\mathrm{kg}$ for the trials with deprivation.

Determinations were made on $2.5 \mathrm{ml}$ portions of each blood sample for glucose (glucose oxidase (EC 1.1.3.4) technique, Hill \& Kessler, 1961), and amino-N (trinitrobenzenesulphonate TNBS, Palmer \& Peters, 1966). The remainder of each blood sample was used for determination of individual amino acids (except tryptophan) and regulatory peptides (insulin, glucagon) according to techniques already described (Rerat et al. 1985, 1988b). 
Table 1. Composition of the diet* $(\mathrm{g} / \mathrm{kg})$ used before and during experiments

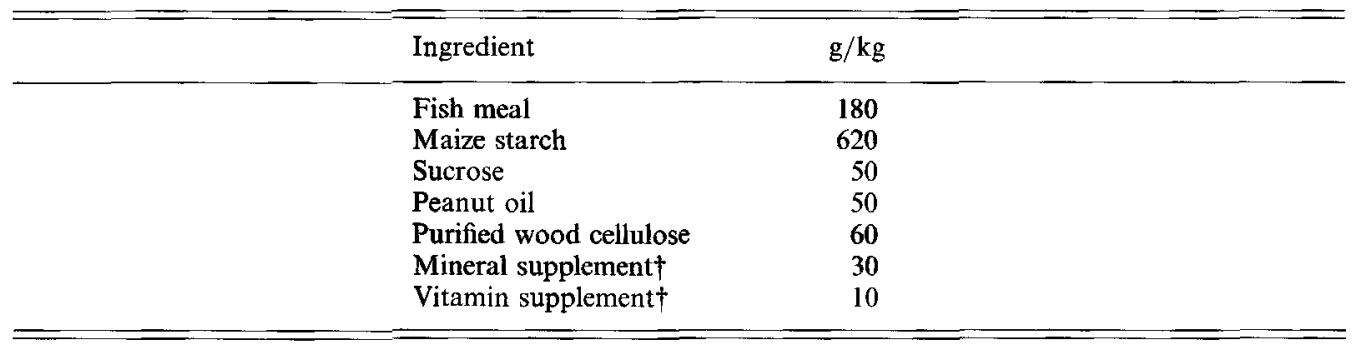

* DM $913 \mathrm{~g} / \mathrm{kg}$ fresh matter; N 21.5 g/kg DM; amino acids (AA) (g/kg fresh matter) His 2.5, Lys 9.0, Phe 4.9,

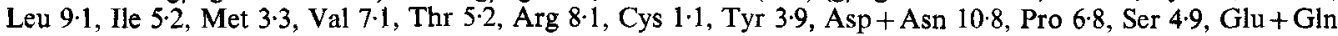
16.5, Ala $8 \cdot 0$, Gly $9 \cdot 1$, total AA $115 \cdot 5$, total AA-N $16 \cdot 3$.

$\dagger$ As described by Henry \& Rérat (1964).

The validation of the electromagnetic technique for determining blood flow had been assessed previously (Rérat et al. 1980; Rérat \& Vaugelade, 1983).

\section{Calculations and limits of the method}

The method used for studying absorption (Rérat, 1971; Rérat et al. 1980) consists of quantifying the exchanges $(q)$ between the blood and the digestive lumen by a simultaneous measurement of the difference between the efferent intestinal (portal) blood and the afferent (arterial) blood concentrations $(\mathrm{Cp}-\mathrm{Ca})$ and the blood flow $\mathrm{D}$ in the portal vein according to the formula $\mathrm{q}=(\mathrm{Cp}-\mathrm{Ca}) \mathrm{D} d \mathrm{~d}$ where $\mathrm{dt}$ is the short time $(5 \mathrm{~min})$ during which variables can be considered as constant. The exchanges $Q(a p v)$ over longer periods are obtained by summing the amounts (q) recorded within these short periods. However, as the nutrients coming from the intestinal lumen or the blood may be metabolized or catabolized in the gut wall, the formulas only give the crude result between the processes of absorption, uptake by the intestinal wall and secretion. When $(\mathrm{Cp}-\mathrm{Ca})$ is positive the data obtained represent the overall excess of absorption over gut tissue metabolism. When this difference is negative, i.e. when arterial concentration is higher than portal concentration, the data represent the excess of gut wall uptake from the blood and from the luminal origin over absorption. If the absolute differences $(\mathrm{Cp}-\mathrm{Ca})$ are used, an apparent intestinal balance is obtained which is the overall result of absorption processes.

\section{Statistical methods}

Statistical analysis (Snedecor \& Cochran, 1967) involved standard error of the mean and comparison of two groups of data by Student's paired $t$ test.

\section{RESULTS}

\section{Portal blood flow rate}

The mean portal blood flow rate during the postprandial period was not affected by whether the pancreatic juice was reintroduced (C) or not (D). In animals without deprivation the portal blood flow rate was 2619 (SEM 67) $\mathrm{ml} / \mathrm{min}(49.9$ (SEM 3.4) $\mathrm{ml} / \mathrm{min}$ per $\mathrm{kg}$ ); when pancreatic secretion was diverted it was 2575 (SEM 123) $\mathrm{ml} / \mathrm{min}(47.6$ (SEM 3.6) $\mathrm{ml} / \mathrm{min}$ per $\mathrm{kg}$ ).

\section{Appearance of glucose in the portal blood}

In the trials without deprivation (C), glycaemia was not different at the beginning of the meal (initial concentration IC) in the portal (767 (SEM 52) $\mathrm{mg} / 1, n$ 5) and the arterial blood 


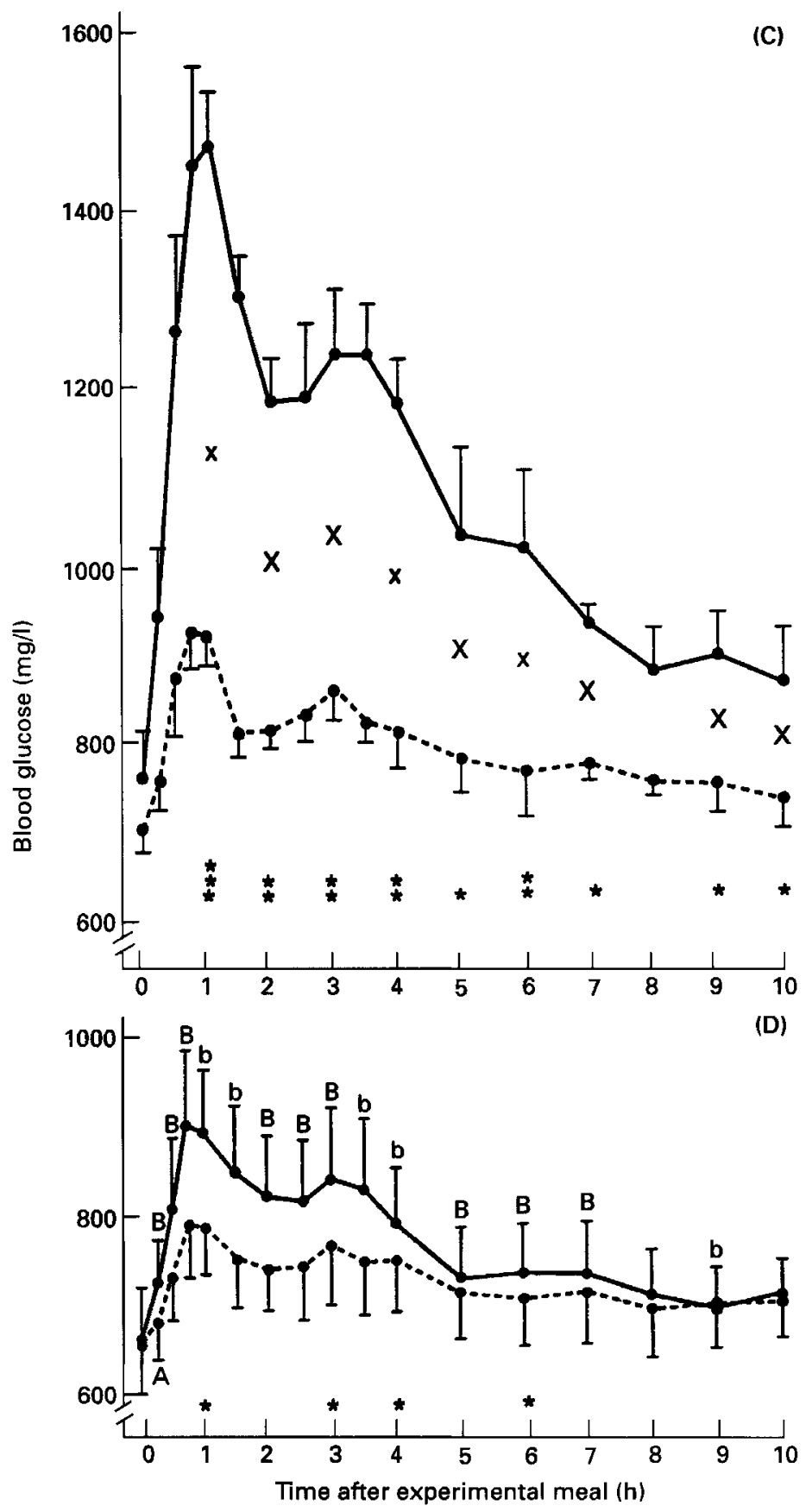

Fig. 1. Changes in blood glucose concentrations $(\mathrm{mg} / 1)$ in the portal vein $(-)$ and carotid artery $(--)_{-}$after a meal (see Table 1 ) in pigs $(n)$ without $(C)$ or with (D) diversion of the pancreatic secretion. Values are means with their standard errors represented by vertical bars. Significance of the porto-arterial differences; ${ }^{*} P<0 \cdot 05$; ** $P<0.01 ; * * * P<0.001$. Significance of the comparison $\mathrm{C} v$. D: arterial concentrations $\mathrm{A}, P<0.05$; portal concentrations $\mathrm{B}, P<0.05$, b, $P<0.01$; porto-arterial differences: $\mathrm{X}, P<0.05, \mathrm{x}, P<0.01$. 


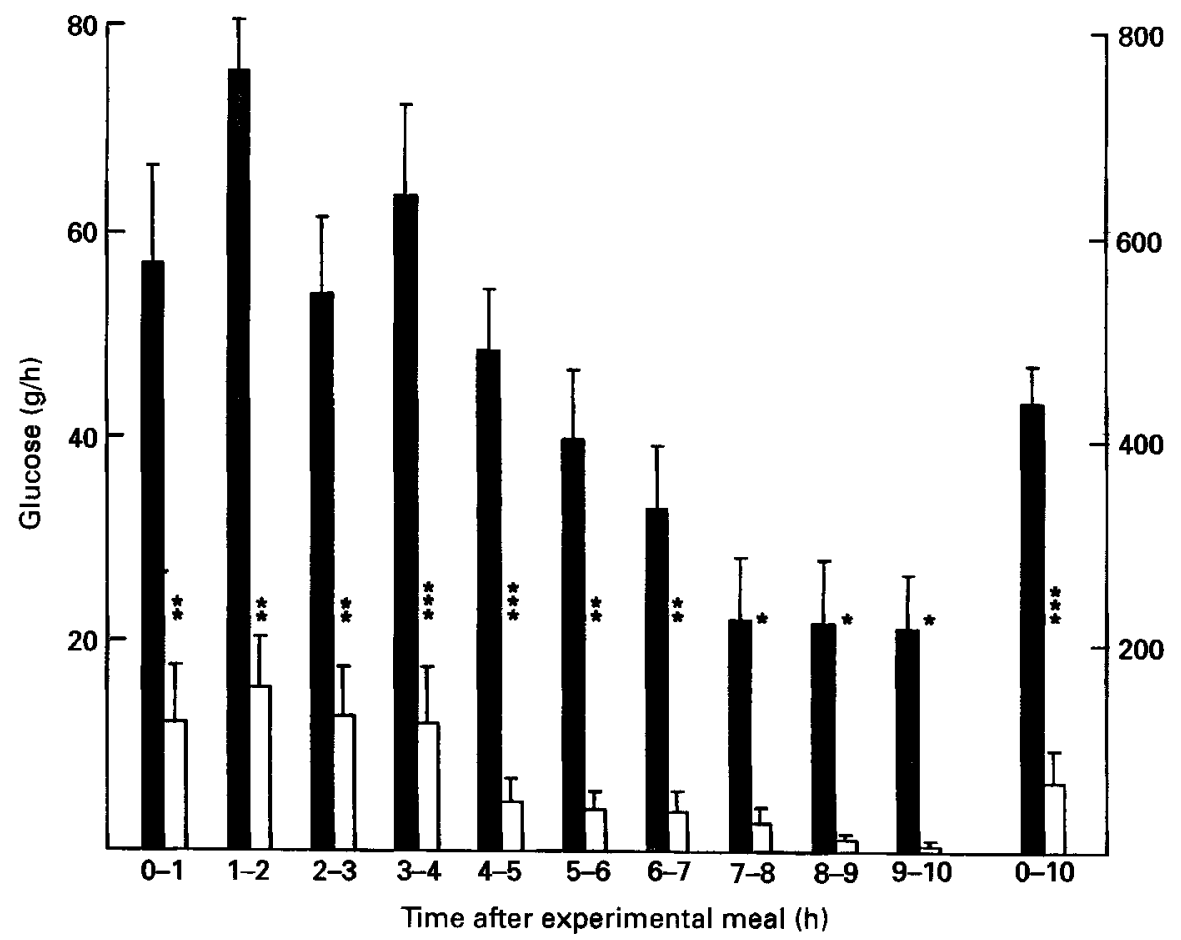

Fig, 2. Changes in amounts of glucose $(\mathrm{g} / \mathrm{h})$ appearing in the portal blood at various time-intervals after a meal (see Table 1) in pigs without (C, $\square$ ) or with (D, $\square$ ) diversion of the exocrine pancreatic secretion. Values are means for five pigs, with their standard errors represented by vertical bars. Significance of the differences between treatments: $* P<0.05,{ }^{* *} P<0.01,{ }^{* * *} P<0.001$.

(705 (SEM 23) $\mathrm{mg} / \mathrm{l}, n$ 5). It showed a sudden rise and reached a maximum value (Fig. 1) $1 \mathrm{~h}$ and $45 \mathrm{~min}$ respectively after the beginning of the meal in the portal (192\% IC) and the arterial blood $(131 \%$ IC). Thereafter there was a slow decrease until the blood concentrations returned to suboptimal values $(105-115 \%$ IC) $8-10 \mathrm{~h}$ after the meal. The differences between portal and arterial concentrations were significant except at the 8 th hour. The $\mathrm{Cp}-\mathrm{Ca}$ value increased up to 550 (SEM 30) $\mathrm{mg} / \mathrm{l}$ ( $74 \%$ IC) after $1 \mathrm{~h}$, then plateaued at about $370 \mathrm{mg} / 1$ for $3 \mathrm{~h}(50 \% \mathrm{IC}), 250 \mathrm{mg} / 1$ during the 5 th and 6 th hours $(34 \%$ IC), and $135 \mathrm{mg} / \mathrm{l}$ during the last $4 \mathrm{~h}$ (19\% IC).

In the trials with pancreatic deprivation (D), glycaemia, which was nearly identical at the beginning of the meal in the portal $(656$ (SEM 60) $\mathrm{mg} / \mathrm{l}, n$ 5) and the arterial blood (654 (SEM 52) $\mathrm{mg} / 1, n$ 5), reached a peak 45 min after the meal (Fig. 1) which was higher $(P<0.05)$ in the portal $(131 \%$ IC) than in the arterial blood $(121 \%$ IC). Then, glycaemia decreased slowly to a level close to the initial value (106\% IC) at the 10 th hour after a low plateau (about 107-110\% IC) between the 6th and the 9th hours. The differences between the portal and arterial blood were low and mostly not significant. Glycaemia was significantly lower in the deprived animals than in the non-deprived animals in the portal blood, but not in the arterial blood $(P<0.05$ only at $15 \mathrm{~min})$. The $\mathrm{Cp}-\mathrm{Ca}$ differences, maximum after $1 \mathrm{~h}$ (104 (SEM 34) $\mathrm{mg} / 1 ; 16 \%$ IC), decreased to values close to zero between the 7 th and the 10th hours; they were significantly lower (five to ten times) than in the nondeprived animals.

In the $\mathrm{C}$ trials (Fig. 2) a considerable amount of glucose (12\% intake) was absorbed during the 1 st hour after the meal; the hourly amount absorbed increased up to a maximum 


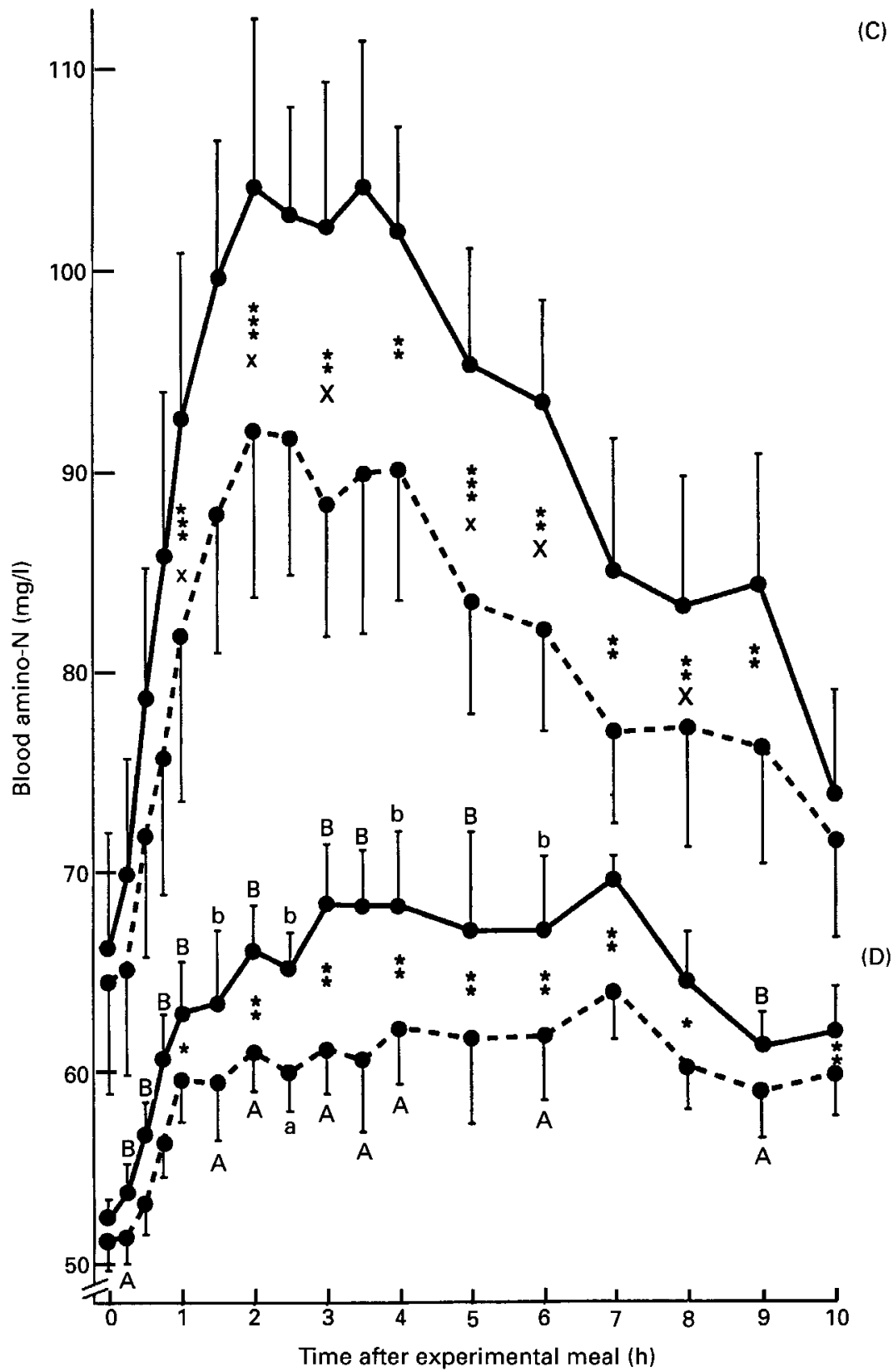

Fig. 3. Changes in blood amino-nitrogen concentrations $(\mathrm{mg} / \mathrm{l})$ in the portal vein (-) and carotid artery (---) after a meal (see Table 1) in pigs without (C) or with (D) diversion of the exocrine pancreatic secretion. Values are means for five pigs, with their standard errors represented by vertical bars. Statistical significance of the portoarterial differences: $* P<0.05, * * P<0 \cdot 01, * * * P<0.001$. Significance of the comparison $\mathrm{C} v$. D: arterial concentrations A, $P<0.05$, a, $P<0.01$; portal concentrations $\mathrm{B}, P<0.05$, b, $P<0.01$; porto-arterial differences: $\mathrm{X}, P<0.05, \mathrm{x}, P<0.01$. 


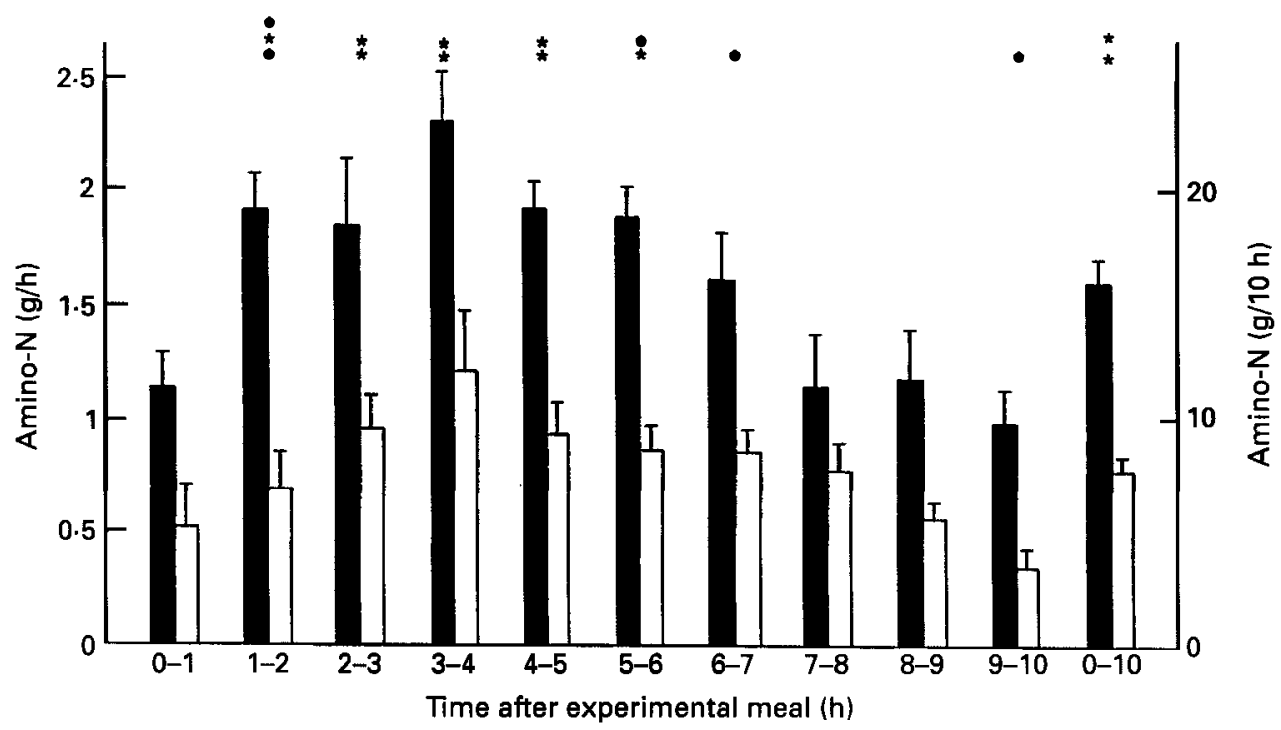

Fig. 4. Changes in the amounts of amino-nitrogen (measured by the trinitrobenzene sulphonate method) (g/h) appearing in the portal blood at various time-intervals after a meal (see Table 1) in pigs without (C, 1 ) or with $(\mathrm{D}, \square)$ diversion of the exocrine pancreatic secretion. Values are means for five pigs with their standard errors represented by vertical bars. Significance of the differences between treatments: ${ }^{*} P<0.05,{ }^{* *} P<0.01$, *** $P<0.001$.

during the 2 nd hour ( $16 \%$ intake), then decreased slowly to smaller values during the last $3 \mathrm{~h}$ (about $5 \%$ intake). The changes with time were the same in the deprived animals, but the amounts were significantly lower (five to ten times) than in the non-deprived animals.

The cumulative amounts of glucose absorbed over $10 \mathrm{~h}$ were lower $(P<0.001)$ during deprivation than during the $\mathrm{C}$ trials, the total $10 \mathrm{~h}$ absorption values as a percentage of the total glucose ingested being 13.8 and $89 \cdot 2 \%$ respectively.

\section{Kinetics of amino-nitrogen appearance in the portal blood}

In the $\mathrm{C}$ trials (Fig. 3), blood levels of amino-N, according to the TNBS technique, were not different at the beginning of the meal in the portal (66.5 (SEM 5.9) $\mathrm{mg} / 1, n$ ) or the arterial blood (64.7 (SEM 5.9) $\mathrm{mg} / \mathrm{l}, n$ 5). They increased up to a peak at the 2 nd hour (Cp $159 \%$ IC; Ca $144 \%$ IC) then, after a plateau lasting $2 \mathrm{~h}$, they decreased slowly until the 10th hour ( $111 \%$ IC). The $\mathrm{Cp}-\mathrm{Ca}$ differences, always significant except at the meal time, increased to a maximum at the 3rd hour and plateaued until the 6th hour (17-22\% IC), then decreased slowly to low values (NS, $4 \%$ IC) at the 10th hour. In deprived animals (Fig. 3) the blood levels at the beginning of the meal were identical in the portal (52.3 (SEM 1.5) $\mathrm{mg} / \mathrm{l}$ ) and arterial blood (51.9 (SEM 1.5) $\mathrm{mg} / \mathrm{l})$, but lower (NS) than in the C trials. They increased up to a plateau reached at the $3 \mathrm{rd}$ hour (Cp $131 \%$ IC; Ca $118 \%$ IC) followed by a peak at the 7 th hour (Cp $134 \%$ IC; Ca $125 \%$ IC) and slowly decreased to rather high values at the 10th hour (Cp 119\% IC; Ca 117\% IC), the differences between the concentrations in the two systems being significant except at the 9 th hour (NS). In the portal blood the amino- $\mathrm{N}$ concentrations were mostly significantly lower than during the $\mathrm{C}$ trials, but this was more seldom in the arterial blood. The $\mathrm{Cp}-\mathrm{Ca}$ differences, which were maximum (14\% IC) at the 3rd hour, were mostly significantly lower than those observed during the $\mathrm{C}$ trials.

The hourly amounts of amino-N appearing in the portal blood (Fig. 4) increased between the 1 st and the 4 th hours, the maximum representing 14.5\% (non-deprived animals: group 
Table 2. Changes in hourly amounts $(\mathrm{g} / \mathrm{h})$ of total amino acids $(T A A)$ and total amino acid nitrogen (TAAN) appearing in the portal blood following the intake of a meal by pigs with $(D)$ or without $(C)$ diversion of the pancreatic exocrine secretion $\dagger$

(Mean values with their standard errors for five pigs)

\begin{tabular}{|c|c|c|c|c|c|c|c|c|}
\hline \multirow{3}{*}{$\begin{array}{l}\text { Time after } \\
\text { intake (h) }\end{array}$} & \multicolumn{4}{|c|}{ TAA } & \multicolumn{4}{|c|}{ TAAN } \\
\hline & \multicolumn{2}{|c|}{$\mathrm{C}$} & \multicolumn{2}{|c|}{$\mathrm{D}$} & \multicolumn{2}{|c|}{$\mathrm{C}$} & \multicolumn{2}{|c|}{$\mathrm{D}$} \\
\hline & Mean & SEM & Mean & SEM & Mean & SEM & Mean & SEM \\
\hline 1 & $8 \cdot 06$ & 0.76 & $3 \cdot 14^{*}$ & 0.43 & $1 \cdot 32$ & $0 \cdot 12$ & $0.51^{* *}$ & 0.07 \\
\hline 2 & $12 \cdot 19$ & 0.47 & $4 \cdot 22^{* *}$ & 0.67 & 1.95 & 0.08 & $0.70^{* *}$ & 0.11 \\
\hline 3 & 11.53 & 0.92 & $5 \cdot 61^{* *}$ & 0.96 & 1.84 & $0-15$ & $0.91^{* * *}$ & 0.16 \\
\hline 4 & $14 \cdot 30$ & $1 \cdot 19$ & $6 \cdot 14^{* *}$ & 0.98 & $2 \cdot 18$ & $0 \cdot 18$ & $1.00^{* *}$ & $0 \cdot 16$ \\
\hline 5 & $11 \cdot 56$ & 0.51 & $5 \cdot 69^{*}$ & $1 \cdot 30$ & 1.89 & 0.08 & $0.93^{*}$ & 0.21 \\
\hline 6 & 10.61 & 0.56 & $5 \cdot 88^{* *}$ & 0.75 & 1.73 & $0-09$ & $0.97^{* *}$ & 0.12 \\
\hline 7 & $8 \cdot 30$ & 0.84 & $5 \cdot 38^{*}$ & 0.72 & $1 \cdot 33$ & $0 \cdot 13$ & $0-88^{*}$ & 0.12 \\
\hline 8 & $7 \cdot 70$ & 0.85 & $5 \cdot 38 * * *$ & 0.76 & 1.27 & $0 \cdot 14$ & $0.89^{* * *}$ & 0.13 \\
\hline 9 & 8.78 & 1.86 & $4 \cdot 45^{*}$ & 0.73 & 1.46 & 0.20 & $0.74^{*}$ & $0 \cdot 12$ \\
\hline 10 & 5.74 & 0.74 & $3 \cdot 57$ & 0.78 & $0-97$ & 0.13 & 0.59 & 0.13 \\
\hline $0-10$ & $98 \cdot 76$ & 3.59 & $49 \cdot 46^{* * *}$ & 5.90 & 16.06 & 0.50 & $8 \cdot 13^{* * *}$ & 0.97 \\
\hline
\end{tabular}

Mean values were significantly different from those for pigs without pancreatic diversion: ${ }^{*} P<0 \cdot 05$, ${ }^{* *} P<0.01,{ }^{* * *} P<0.001$.

+ For details of diets and procedures, see Table 1 and pp. 176-177.

TAA intake was $92 \cdot 3 \mathrm{~g}$.

C) and $15.9 \%$ (deprived animals: group D) of the total amount absorbed within $10 \mathrm{~h}$. Then, they decreased slowly until the 10th hour to values representing $6 \cdot 2 \%$ (group C) to $4 \cdot 1 \%$ (group D) of the total amount absorbed. During the total postprandial period, hourly amounts were lower (between two and three times, between the 2nd and the 10th hours) in the deprived animals than in the non-deprived animals. Accordingly, the cumulative absorbed amounts for $10 \mathrm{~h}$ were lower $(P<0.001)$ in the deprived animals than in the nondeprived animals, the total $10 \mathrm{~h}$ absorption yields being $48.1 \%$ and $100 \%$ respectively.

\section{Kinetics of amino acid appearance in the portal blood}

Hourly amounts of amino- $\mathrm{N}$ from total amino acids appearing in the portal blood (Table 2) were generally close ( $\pm 5 \%$ ) to amino-N measured with the TNBS technique (Fig. 4). During the whole postprandial period the cumulative amounts of amino-N absorbed as amino acids were identical to (non-deprived) or slightly higher than (6\%, deprived animals) the amino-N measured with the TNBS technique. Thus the changes with time in the hourly amounts of total amino acids appearing in the portal blood were the same as those described for TNBS amino-N. They increased from the 1st hour to a maximum attained at the 4th hour (group C: $177 \%$ of 1st hour amount; group D: 195\%) then decreased to still noticeable amounts (group C: $71 \%$ of 1 st hour amount; group D: $114 \%$ ) at the 10 th hour. According to the time after the meal, the hourly amounts appearing in the portal blood of the animals from group D represented between one third (first $2 \mathrm{~h}$ ), one half (between 3rd and 6th hours) and two thirds (last hours) of those found in the animals of group C, the differences being significant (except at the 10th hour, NS) resulting in a $10 \mathrm{~h}$ absorption of total amino acids of between $53.6 \%$ (D) and $107.0 \%$ (C) $(P<0.001)$.

Hourly amounts of individual amino acids absorbed showed generally the same trends, i.e. they increased in group $\mathrm{C}$ up to a maximum between the 4th and the 5th hours, then 
Table 3. Changes in the hourly absorption coefficients (\%) of amino acids (amount appearing in the portal vein/amount ingested) according to time (1st hour, 4th hour maximum) and the mean over $10 \mathrm{~h}$ after a meal in pigs without $(C)$ or with $(D)$ diversion of the exocrine pancreatic secretion $\dagger$

\begin{tabular}{|c|c|c|c|c|c|c|c|}
\hline \multirow[t]{2}{*}{ Time after the meal (h)... } & \multicolumn{2}{|c|}{1} & \multicolumn{2}{|c|}{4} & \multicolumn{2}{|c|}{ Mean over $10 \mathrm{~h}$} & \multirow[b]{2}{*}{ Intake $(\mathrm{g})$} \\
\hline & $\mathrm{C}$ & $\mathrm{D}$ & $\mathrm{C}$ & $\mathrm{D}$ & $\mathrm{C}$ & $\mathrm{D}$ & \\
\hline His & $9 \cdot 6$ & $2 \cdot 7^{* *}$ & $22 \cdot 8$ & $7 \cdot 1 * * *$ & $13 \cdot 5$ & $4 \cdot 9 * *$ & 1.98 \\
\hline Lys & $8 \cdot 1$ & $2 \cdot 8^{*}$ & $17 \cdot 7$ & $5 \cdot 5^{* *}$ & $10 \cdot 7$ & $4 \cdot 1 * * *$ & $7 \cdot 19$ \\
\hline Phe & $7 \cdot 3$ & $2 \cdot 1$ & $15 \cdot 3$ & $6 \cdot 0^{* *}$ & $10 \cdot 2$ & $4 \cdot 3^{* *}$ & $3 \cdot 92$ \\
\hline Leu & $8 \cdot 2$ & $2 \cdot 4^{* *}$ & $16 \cdot 0$ & $6 \cdot 8^{* *}$ & $10 \cdot 2$ & $4 \cdot 6^{* *}$ & $7 \cdot 26$ \\
\hline Ile & $7 \cdot 3$ & $2 \cdot 2 * *$ & $15 \cdot 3$ & $4 \cdot 8 * *$ & $10 \cdot 8$ & $4 \cdot 0^{* * *}$ & $4 \cdot 13$ \\
\hline Met & $9 \cdot 3$ & $2 \cdot 9^{* *}$ & $17 \cdot 3$ & $7 \cdot 0^{* *}$ & $12 \cdot 2$ & $5 \cdot 5^{* * *}$ & 2.64 \\
\hline Val & $8 \cdot 0$ & $2 \cdot 5^{* * *}$ & $14 \cdot 1$ & $3 \cdot 8 * *$ & $9 \cdot 8$ & $3 \cdot 4 * * *$ & $5 \cdot 65$ \\
\hline Thr & $7 \cdot 8$ & $2 \cdot 1^{* *}$ & $13 \cdot 3$ & $7 \cdot 4$ & $10 \cdot 0$ & $4 \cdot 5^{* * *}$ & $4 \cdot 17$ \\
\hline Arg & $9 \cdot 2$ & $2 \cdot 7^{* *}$ & $19 \cdot 1$ & $6 \cdot 6^{*}$ & $12 \cdot 7$ & $5 \cdot 1 * *$ & $6 \cdot 50$ \\
\hline Cys & $1 \cdot 2$ & $2 \cdot 0$ & $3 \cdot 1$ & 0.7 & $2 \cdot 2$ & $1 \cdot 2$ & 0.85 \\
\hline Tyr & $7 \cdot 0$ & $1 \cdot 1^{* *}$ & $13 \cdot 9$ & $6.9 * * *$ & $9 \cdot 5$ & $4 \cdot 4^{* * *}$ & 3.09 \\
\hline TEAA & $8 \cdot 4$ & $2 \cdot 4^{* *}$ & 160 & $5 \cdot 9^{* *}$ & $10 \cdot 7$ & $4 \cdot 3^{* *}$ & $47 \cdot 38$ \\
\hline Asp & $5 \cdot 2$ & $4 \cdot 0$ & $5 \cdot 3$ & $3 \cdot 6$ & $5 \cdot 1$ & $3 \cdot 8$ & \\
\hline+ & & & & & & & 8.66 \\
\hline Asn & $3 \cdot 2$ & $0.9 * * *$ & 6.8 & $2 \cdot 8$ & $4 \cdot 4$ & $2 \cdot 0^{* *}$ & \\
\hline Pro & $8 \cdot 4$ & $3 \cdot 0^{* *}$ & $10 \cdot 4$ & $3 \cdot 3 * *$ & $7 \cdot 4$ & $4 \cdot 2$ & $5 \cdot 43$ \\
\hline Ser & $7 \cdot 3$ & $0 \cdot 7^{* * *}$ & 13.9 & $6 \cdot 3^{*}$ & $10 \cdot 3$ & $3.6 * * *$ & 3.94 \\
\hline Glu & $0 \cdot 1$ & 0 & 0.4 & & $1 \cdot 3$ & 0 & \\
\hline+ & & & & & & & $13 \cdot 19$ \\
\hline Gln & 0.1 & 0 & - & & $0 \cdot 1$ & 0 & \\
\hline Ala & $19 \cdot 4$ & $7 \cdot 0^{* *}$ & $23 \cdot 1$ & $20 \cdot 1 * *$ & $25 \cdot 2$ & $13 \cdot 8 * * *$ & $6 \cdot 41$ \\
\hline Gly & $10 \cdot 0$ & $5 \cdot 1^{*}$ & 16.8 & $19 \cdot 2$ & $10 \cdot 1$ & $6 \cdot 2 *$ & $7 \cdot 30$ \\
\hline TNEAA & $9 \cdot 1$ & $4 \cdot 5^{* * *}$ & $10 \cdot 5$ & $7 \cdot 4^{*}$ & $10 \cdot 6$ & $6 \cdot 5^{* * *}$ & 44.93 \\
\hline TAA & 8.8 & $3 \cdot 4^{* * *}$ & 11.5 & $6 \cdot 7^{* *}$ & 10.7 & $5 \cdot 4^{* * *}$ & $92 \cdot 31$ \\
\hline
\end{tabular}

TEAA, total essential amino acids; TNEAA, total non-essential amino acids; TAA, total amino acids.

Mean values were significantly different from those for pigs without pancreatic diversion, ${ }^{*} P<0 \cdot 05$, ** $P<0.01$, *** $P<0.001$.

$\dagger$ For details of diets and procedures, see Table 1 and pp. 176-177.

\$ Including citrulline, ornithine and taurine.

decreased to minimal values at the 10th hour. In group $D$ the maximum was reached between the $3 \mathrm{rd}$ and the 5 th hours. The absorption coefficient (amount appearing in the portal blood, as a percentage of intake) varied according to amino acids, being much higher when the pancreatic secretion was preserved than when it was diverted. For the whole experimental period during the $\mathrm{C}$ trials (Table 3 ) the absorption rates of total essential amino acids (TEAA) and total non-essential amino acids (TNEAA) were similar, resulting in a TEAA : total amino acids (TAA) ratio of $51 \cdot 1 \%$ in the mixture absorbed, similar to that found in the mixture ingested $(51 \cdot 3 \%)$. Over the whole period of observation some essential amino acids (His, Arg, Met) showed a greater absorption rate than the TEAA, others (Tyr, Cys) a lower one. Amongst the non-essential amino acids, some (Gly, Ser) showed the same absorption rate as the mean TNEAA, some such as Pro, and particularly Glu + Gln and Asp + Asn, a lower one; in contrast, the absorption coefficient of Ala was very high, the amount absorbed being higher than the intake from the 4th hour, showing a synthesis of this amino acid in the gut wall. In the deprived animals (Table 3) the absorption coefficients for the whole experimental period were significantly lower than in the non-deprived animals, except for Cys, Asp, Pro, Glu and Gln (NS). Except for those 
Table 4. Changes in the pattern of essential amino acids (expressed as a percentage of their sum) in the mixture appearing in the portal blood according to the time after the meal in pigs without $(C)$ or with $(D)$ diversion of the exocrine pancreatic secretion $\ddagger$

\begin{tabular}{|c|c|c|c|c|c|c|c|}
\hline \multirow[t]{2}{*}{ Time after the meal (h)... } & \multicolumn{2}{|c|}{2} & \multicolumn{2}{|c|}{4} & \multicolumn{2}{|c|}{10} & \multirow{2}{*}{$\begin{array}{c}\text { Intake } \\
(\mathrm{g})\end{array}$} \\
\hline & $\mathrm{C}$ & D & C & D & $\mathrm{C}$ & D & \\
\hline His & $4 \cdot 52$ & $5 \cdot 42$ & 5.01 & $4 \cdot 69$ & $5 \cdot 31$ & $4 \cdot 53^{*}$ & $4 \cdot 16$ \\
\hline Lys & $13 \cdot 50$ & $15 \cdot 82$ & $15 \cdot 01$ & $13 \cdot 30$ & $15 \cdot 34$ & 14.09 & $15 \cdot 17$ \\
\hline Phe & $7 \cdot 46$ & $7 \cdot 11$ & 7.83 & $8 \cdot 10$ & 7.95 & $8 \cdot 18$ & $8 \cdot 28$ \\
\hline Leu & $15 \cdot 73$ & $15 \cdot 53$ & $15 \cdot 57$ & $16 \cdot 64$ & $14 \cdot 66$ & $16 \cdot 34$ & $15 \cdot 33$ \\
\hline Ile & 8.79 & $8 \cdot 14$ & 8.85 & $8 \cdot 00$ & $8 \cdot 76$ & 7.96 & $8 \cdot 71$ \\
\hline Met & 6.24 & $7 \cdot 44$ & $6 \cdot 23$ & $7 \cdot 02$ & 6.40 & $7 \cdot 38$ & $5 \cdot 56$ \\
\hline Val & $11 \cdot 56$ & $10 \cdot 34$ & 10.89 & $9 \cdot 75$ & $11 \cdot 01$ & $9 \cdot 16 \dagger$ & $11 \cdot 92$ \\
\hline Thr & 8.88 & $7 \cdot 36$ & $8 \cdot 14$ & $8 \cdot 45$ & $8 \cdot 18$ & 9.07 & 8.80 \\
\hline Arg & 16.97 & $19 \cdot 50$ & $16 \cdot 21$ & $17 \cdot 50$ & $16 \cdot 26$ & $16 \cdot 32$ & $13 \cdot 71$ \\
\hline Cys & 0.28 & 0.53 & $0 \cdot 30$ & 0.46 & 0.36 & 0.51 & $1 \cdot 78$ \\
\hline Tyr & $6 \cdot 16$ & $3.79 *$ & 5.93 & 5.89 & 5.80 & 6.47 & 6.52 \\
\hline TEAA & 10207 & 2961 & 24472 & 8183 & 51432 & 20693 & \\
\hline
\end{tabular}

TEAA. total essential amino acids (mg).

Mean values were significantly different from those for pigs without pancreatic diversion: ${ }^{*} P<0.05, \dagger P<0.06$ (NS).

$\$$ For details of diets and procedures, see Table 1 and pp. 176-177.

amino acids they represented $36-46 \%$ (55\% for Ala) of those recorded in group C and the same general trends were observed: higher absorption rate than the mean for His, Met, Arg, and synthesis of Ala; lower absorption rate for Cys, Glu + Gln and Asp + Asn. However, because of the amounts of Cit, Orn, and Tau absorbed which were equivalent whatever the type of treatment, the TEAA: TAA ratio of the absorbed mixture $(41.8 \%$ over $10 \mathrm{~h}$ ) was lower than that of the ingested mixture.

Because of the variable absorption rates of individual amino acids, the composition of the ingested mixtures was modified when appearing in the portal blood. The composition of the absorbed mixture of essential amino acids, according to the time elapsed after the meal in comparison with the composition of the ingested mixture, is given in Table 4 . From the beginning of the absorptive period the mixture of essential amino acids appearing in the portal blood was richer in His, Met and Arg than the ingested mixture. The changes due to the diversion of the pancreatic juice were generally small; they were only significant for Tyr $(P<0.05)$ at the 2 nd hour, and for His $(P<0.05)$ and Val (a trend: $P<0.06)$ at the 10th hour, the mixture appearing after diversion being poorer in these amino acids than when the pancreatic juice was reintroduced.

Some amino acids were taken up by the gut wall, as shown by negative porto-arterial differences. Cumulative amounts within the whole postprandial period are given in Table 5. Most (15.5\% (C) to $36.3 \%$ (D) of TAA absorbed) proceeded from Glu (C: $32.3 \%$; D : $32.3 \%$ ), Gln (C: $44.7 \%$; D: 39.2\%), Tau (C: $5 \cdot 1 \% ; \mathrm{D}: 3.2 \%$ ) and Gly (C: $5.9 \% ; \mathrm{D}$ : $0.7 \%$ ). The amounts taken up by the gut wall were significantly higher after $\mathrm{D}$ trials than after $\mathrm{C}$ trials only for Val, Thr, Ser and TEAA, and were quite similar for the other amino acids.

Kinetics of secretion of insulin and glucagon

During the $\mathrm{C}$ trials (Fig. 5) the portal concentrations of insulin were always higher than the arterial ones, but there were significant differences only during the first $5 \mathrm{~h}$ and the last $2 \mathrm{~h}$. At the meal time this difference was small (Cp 34 (SEM 12) mIU/1; Ca 14 (SEM 4) mIU/1, 
Table 5. Total amounts $(g)$ of individual amino acids appearing in the portal blood and taken $u p$ by the intestinal wall, within 10 h after a meal in pigs without $(C)$ or with $(D)$ diversion of the exocrine pancreatic secretion $\dagger$

(Mean values with their standard errors for five pigs)

\begin{tabular}{|c|c|c|c|c|c|c|c|c|c|}
\hline & \multirow[b]{3}{*}{ Intake } & \multicolumn{4}{|c|}{ Appearing in the portal blood } & \multicolumn{4}{|c|}{ Taken up by the intestinal wall } \\
\hline & & \multicolumn{2}{|c|}{ C } & \multicolumn{2}{|c|}{$\mathrm{D}$} & \multicolumn{2}{|c|}{$\mathrm{C}$} & \multicolumn{2}{|c|}{$\mathrm{D}$} \\
\hline & & Mean & SEM & Mean & SEM & Mean & SEM & Mean & SEM \\
\hline His & 1.98 & $2 \cdot 68$ & 0.11 & $0 \cdot 98 * *$ & 0.20 & 0 & 0 & 0.04 & $0 \cdot 02$ \\
\hline Lys & $7 \cdot 19$ & $7 \cdot 72$ & $0 \cdot 31$ & $2 \cdot 98^{* * *}$ & 0.48 & 0.01 & 0 & $0 \cdot 23$ & $0 \cdot 10$ \\
\hline Phe & 3.92 & $4 \cdot 03$ & 0.25 & $1 \cdot 67^{* *}$ & 0.25 & 0 & 0 & 0.05 & 0.03 \\
\hline Leu & $7 \cdot 26$ & $7 \cdot 44$ & $0 \cdot 51$ & $3 \cdot 35^{* *}$ & 0.56 & 0 & 0 & 0.07 & 0.03 \\
\hline Ile & $4 \cdot 13$ & $4 \cdot 44$ & 0.27 & $1 \cdot 66^{* *}$ & $0 \cdot 34$ & 0 & 0 & 0.13 & 0.04 \\
\hline Met & $2 \cdot 64$ & $3 \cdot 23$ & 0.11 & $1 \cdot 46^{* * *}$ & 0.15 & 0 & 0 & 0.02 & 0.01 \\
\hline Val & $5 \cdot 65$ & $5 \cdot 53$ & $0 \cdot 18$ & $1 \cdot 94 * * *$ & $0 \cdot 32$ & 0.01 & 0 & $0 \cdot 16^{* *}$ & 0.03 \\
\hline Thr & $4 \cdot 17$ & $4 \cdot 17$ & 0.42 & $1.90 * * *$ & 0.39 & 0.03 & $0 \cdot 02$ & $0.17^{*}$ & 0.06 \\
\hline Arg & $6 \cdot 50$ & $8 \cdot 26$ & 0.65 & $3 \cdot 30^{* *}$ & $0 \cdot 36$ & 0 & 0 & 0.04 & 0.02 \\
\hline Cys & 0.85 & $0 \cdot 18$ & 0.04 & $0 \cdot 10$ & 0.02 & $0 \cdot 28$ & $0 \cdot 04$ & 0.44 & 0.11 \\
\hline Tyr & 3.09 & $2 \cdot 94$ & 0.21 & $1.35 * *$ & 0.19 & 0.01 & 0.01 & 0.07 & 0.02 \\
\hline EAA & $47 \cdot 38$ & $50 \cdot 50$ & $2 \cdot 29$ & $20 \cdot 68^{* *}$ & $2 \cdot 73$ & 0.34 & 0.06 & $1 \cdot 42^{*}$ & 0.20 \\
\hline Asp & $8 \cdot 66$ & $4 \cdot 43$ & 0.45 & $3 \cdot 31$ & 0.53 & 0.05 & 0.04 & 0.25 & 0.21 \\
\hline Asn & - & 3.90 & $0 \cdot 16$ & $1 \cdot 76^{* *}$ & 0.23 & 0.01 & 0.01 & 0.04 & 0.03 \\
\hline Pro & $5 \cdot 43$ & 4.04 & 0.51 & $2 \cdot 29$ & 0.45 & 0.79 & 0.40 & 0.58 & 0.39 \\
\hline Ser & 3.94 & 4.06 & 0.26 & $1-42^{* * *}$ & 0.33 & 0 & 0 & $0 \cdot 28^{*}$ & $0-08$ \\
\hline Glu & $13 \cdot 19$ & 0.17 & 0.06 & 0.01 & 0.01 & $4 \cdot 80$ & 0.54 & 5.80 & 0.38 \\
\hline Gln & - & 0.01 & 0.01 & 0 & 0 & $6 \cdot 86$ & 0.58 & 7.03 & 0.73 \\
\hline Ala & $6 \cdot 41$ & $16 \cdot 18$ & 0.47 & $8 \cdot 86^{* * *}$ & 0.94 & 0 & 0 & 0 & 0 \\
\hline Gly & $7 \cdot 30$ & $7 \cdot 41$ & 0.45 & $4 \cdot 49^{*}$ & 0.88 & 0.91 & 0.53 & 0.13 & $0-08$ \\
\hline Orn & - & $1 \cdot 38$ & 0.29 & 1.06 & $0 \cdot 26$ & $0 \cdot 38$ & $0 \cdot 20$ & 0.39 & 0.06 \\
\hline Cit & - & $3 \cdot 43$ & 0.55 & 3.88 & 0.71 & 0.03 & 0.02 & 0.01 & 0.01 \\
\hline $\mathrm{Tau}$ & - & $2 \cdot 81$ & 0.87 & $1 \cdot 40^{*}$ & 0.24 & 0.77 & $0 \cdot 14$ & $1 \cdot 39$ & 0.26 \\
\hline NEAA & 44.93 & $48 \cdot 34$ & 1.96 & $28 \cdot 49 * * *$ & 0.37 & $14 \cdot 61$ & $1 \cdot 31$ & 15.90 & 0.95 \\
\hline Total AA & $92 \cdot 31$ & $98 \cdot 76$ & $3 \cdot 59$ & $49 \cdot 46^{* * *}$ & $5 \cdot 90$ & $15 \cdot 34$ & $1 \cdot 36$ & 17.95 & 1.45 \\
\hline
\end{tabular}

EAA, essential amino acids; NEAA, non-essential amino acids; AA, amino acids.

Mean values were significantly different from those for pigs without pancreatic diversion: ${ }^{*} P<0.05$, ** $P<0.01, * * * P<0.001$.

† For details of diets and procedures, see Table 1 and pp. 176-177.

$P<0.05)$. Afterwards, the concentrations (mIU/l) increased considerably until $45 \mathrm{~min}(\mathrm{Cp}$ 139 (SEM 74); Ca 87 (SEM 61), $P<0.01$ ) then decreased rapidly until the 2 nd hour (Cp 79 (SEM 18); Ca 42 (SEM 7), $P<0.05$ ), and slowly decreased to the 5th hour and following when the concentrations (Cp 38 (SEM 5); Ca 22 (SEM 5), $P<0.05$ ) became similar to the initial ones.

In group D the portal concentrations of insulin (Fig. 5) were higher than the arterial ones, but the differences were smaller than in group $\mathrm{C}$ and mostly not significant. At the meal time the concentrations (mIU/1) of insulin (Cp 16 (SEM 3); Ca 11 (SEM 1), NS) were smaller than in group C. They increased until $45 \mathrm{~min}$ (Cp 67 (SEM 14); Ca 36 (SEM 7), NS) then decreased to the 2 nd hour (Cp 28 (SEM 3); Ca 23 (SEM 3), NS). They exhibited a new peak at the 3rd hour (Cp 44 (SEM 8); Ca 28 (SEM 4), $P<0.05$ ) and then decreased slowly to final values at the 10 th hour which were similar to the initial ones.

The total amount of insulin secreted during the whole postprandial period was lower $(P<0.05)$ in deprived animals, representing only $36 \%$ of the amount secreted in animals 

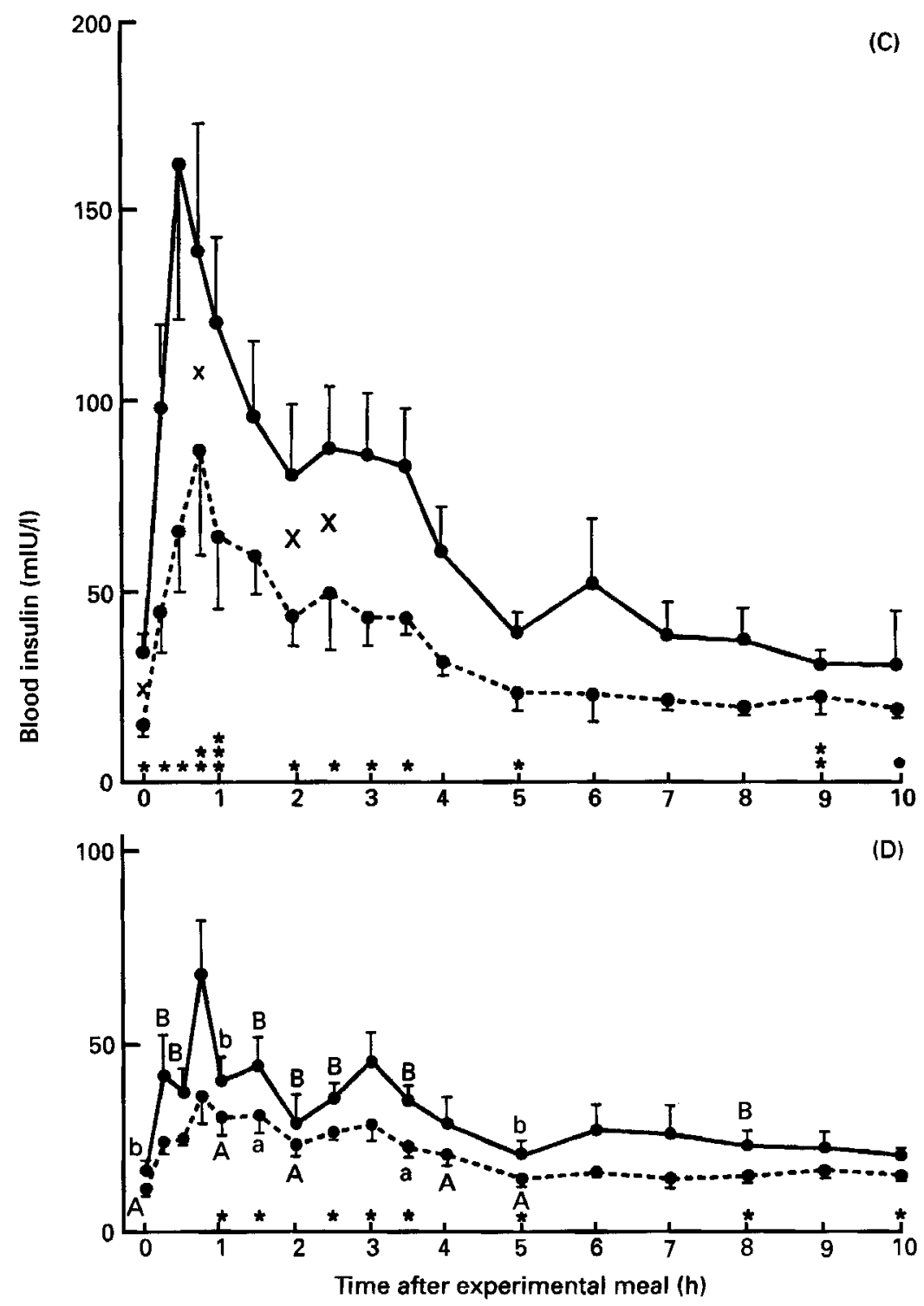

Fig. 5. Changes in blood insulin concentrations (mIU/1) in the portal vein $(-)$ and carotid artery $(---)$ after a meal (see Table 1) in pigs without (C) or with (D) diversion of the exocrine pancreatic secretion. Values are means for five pigs with their standard errors represented by vertical bars. Statistical significance of the portoarterial differences: ${ }^{*} P<0.05,{ }^{* *} P<0.01$, $* * * P<0.001$. Significance of the comparison $\mathrm{C} v$. D: arterial concentrations A, $P<0.05$, a, $P<0.01$; portal concentrations $\mathrm{B}, P<0.05$, b, $P<0.01$; porto-arterial differences: $\mathrm{X}, P<0.05, \mathrm{x}, P<0.01$.

from group C (Fig. 6). The highest secretion occurred during the 1st hour (group C, 9134 (SEM 2097) mIU; group D, 2689 (SEM 897) mIU, $P<0.05$ ) followed by a smaller one during the next $3 \mathrm{~h}$ (group $\mathrm{C}$, between 5000 and $6000 \mathrm{mIU} / \mathrm{h}$; group $\mathrm{D}$, between 1500 and $2000 \mathrm{mIU} / \mathrm{h} ; P<0 \cdot 05)$. Afterwards, insulin secretion was smaller and decreased slowly until the 10th hour, the differences between the two treatments not being significant.

The concentrations of glucagon were always higher (generally significantly from $30 \mathrm{~min}$ 


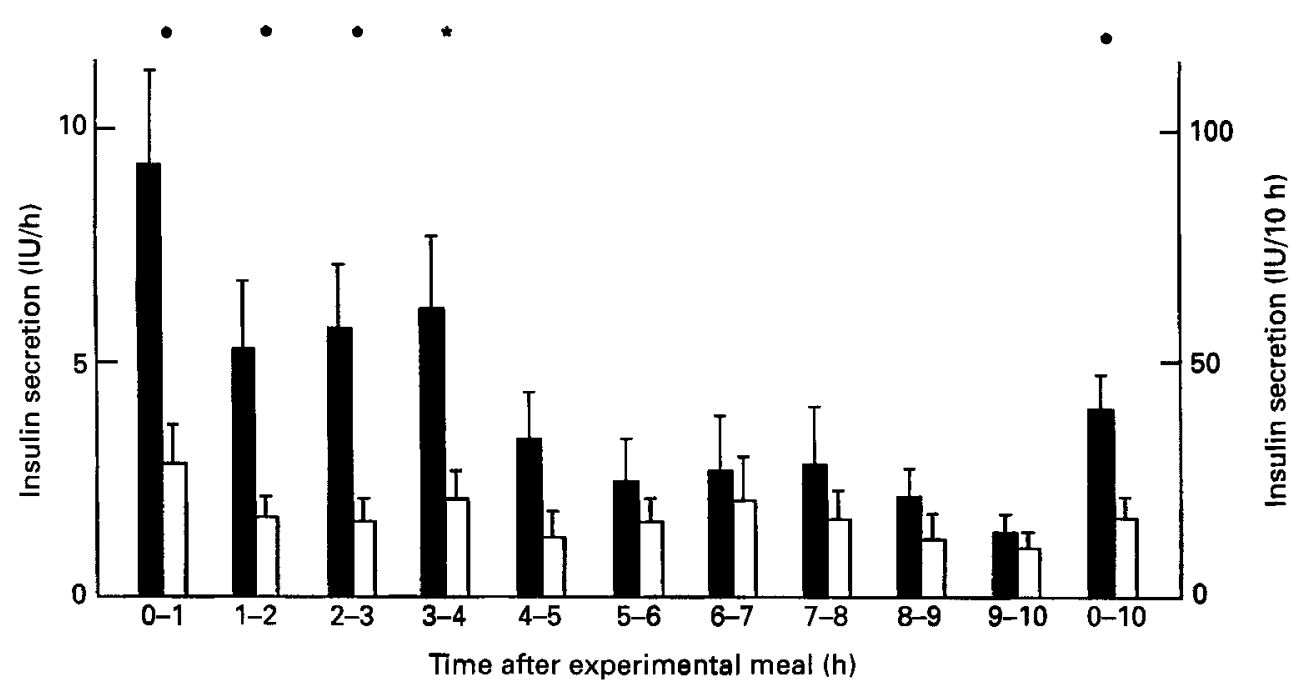

Fig. 6. Changes in the amounts of insulin (IU/h) produced at various time-intervals after a meal (see Table 1) in pigs without $(\mathrm{C}, \square)$ or with $(\mathrm{D}, \square)$ diversion of the exocrine pancreatic secretion. Values are means for five pigs, with their standard errors represented by vertical bars. Statistical significance of the differences between treatments: $* P<0.05$.

after the meal) in the portal than in the arterial blood, whatever the treatment (Fig. 7). During the $\mathrm{C}$ trials the initial concentrations (ng/l) were not significantly different in the portal (107 (SEM 24), $n 5$ ) and the arterial blood ( 80 (SEM 15), $n 5$ ). They increased further until the 4th hour (Cp 189 (SEM 35); Ca 90 (SEM 10), $P<0.05$ ) and decreased afterwards to a concentration similar to the initial one at the 10th hour (Cp 126 (SEM 16), Ca 75 (SEM 13), $P<0.01)$. In group $\mathrm{D}$ the initial concentrations $(\mathrm{ng} / \mathrm{l})$ were not significantly different in the portal (125 (SEM 37), $n 5$ ) and in the arterial blood (89 (SEM 19), $n$ 5). They increased afterwards until the 2nd hour (Cp 193 (SEM 41); Ca 93 (SEM 27), $P<0.05$ ) and then until the 6th hour (Cp 214 (SEM 25); Ca 121 (SEM 16), $P<0.05$ ), then decreased little until the 10th hour (Cp 171 (SEM 39); Ca 96 (SEM 13), $P<0.05$ ). The total amounts of glucagon produced within $10 \mathrm{~h}$ were slightly higher (NS) in group D compared with group C (Fig. 8). As for the hourly amounts, they were generally higher in group $\mathrm{D}$ than in group $\mathrm{C}$, the differences only being significant during the last hour of observation.

\section{DISCUSSION}

Various techniques have been used to study the effects of the absence of pancreatic enzymes in the intestinal lumen on protein and carbohydrate digestion, these being evaluated from the amounts of carbohydrate and protein nutrients appearing in the portal blood. The permanent fistulation of the pancreatic duct (Corring et al. 1972) combined with the permanent fistulation of the duodenum have been performed in order to divert the pancreatic fluid for periods of varying length. Some experiments of permanent recycling or of permanent deprivation have also been made (Corring et al. 1984). In the present study the protocol used to produce an absence of enzymes was based on pancreatic diversion $14 \mathrm{~h}$ before the meal. This length of time was chosen for the following reasons: first, the sectioning of the pancreatic duct during the surgical preparation of the animals prevents the pancreatic secretion from reaching the digestive lumen by a physiological route; second, the digestive transit in the small intestine lasts from 4 to $18 \mathrm{~h}$, which means that the pancreatic 


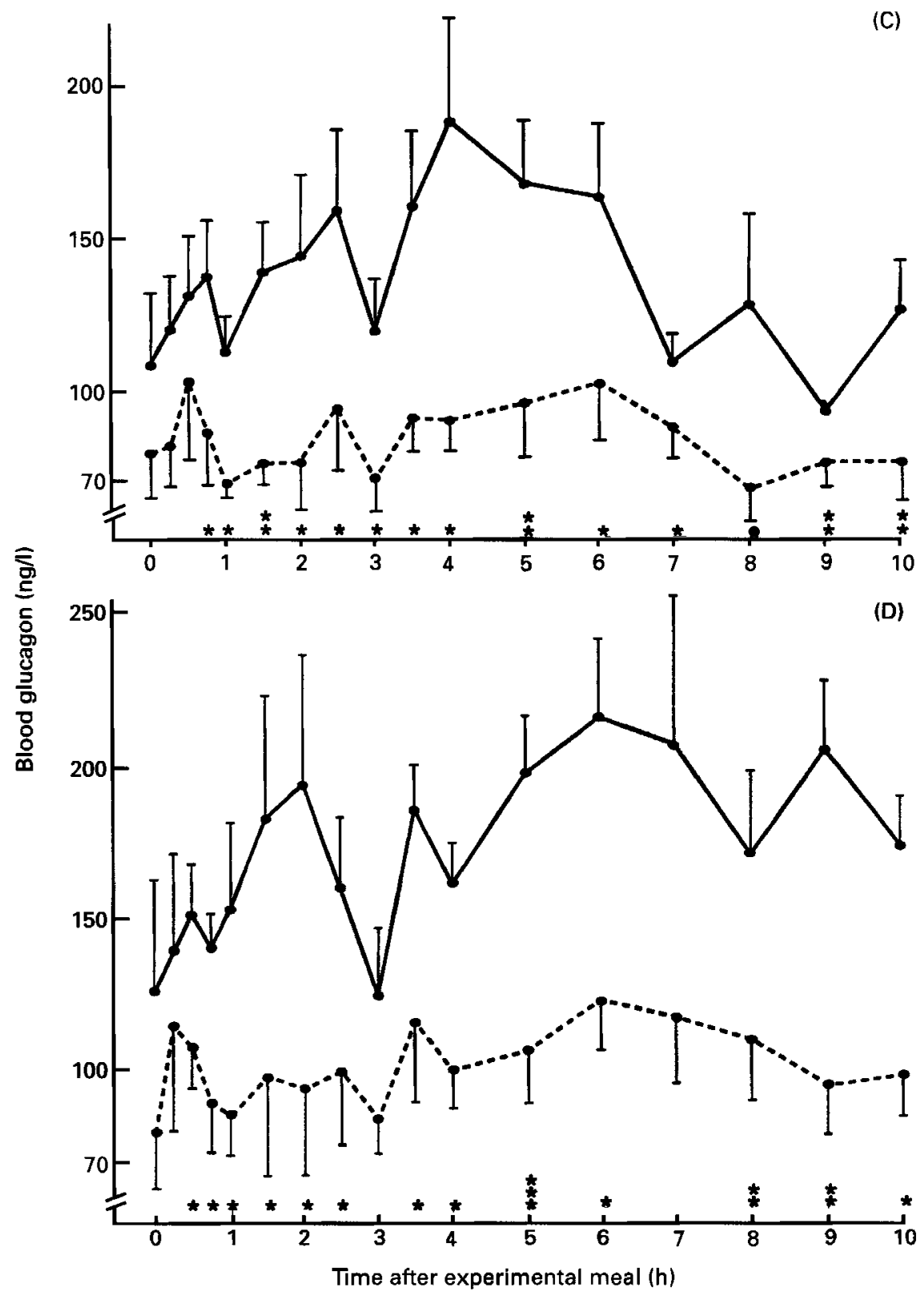

Fig. 7. Changes in blood glucagon concentrations $(\mathrm{ng} / \mathrm{l})$ in the portal vein $(-)$ and the carotid artery $(----)$ after a meal (see Table 1) in pigs without (C) or with (D) diversion of the exocrine pancreatic secretion. Values are means for five pigs, with their standard errors represented by vertical bars. Statistical significance of the portoarterial differences: $* P<0.05,{ }^{* *} P<0.01,{ }^{* * *} P<0.001$.

enzymes secreted $14 \mathrm{~h}$ before the meal cannot be in contact with it. Nevertheless, in the present experiment we confirmed the absence of pancreatic enzymes in the digestive lumen following pancreatic deprivation.

As mentioned previously (p. 177), the method used for studying absorption only allows 


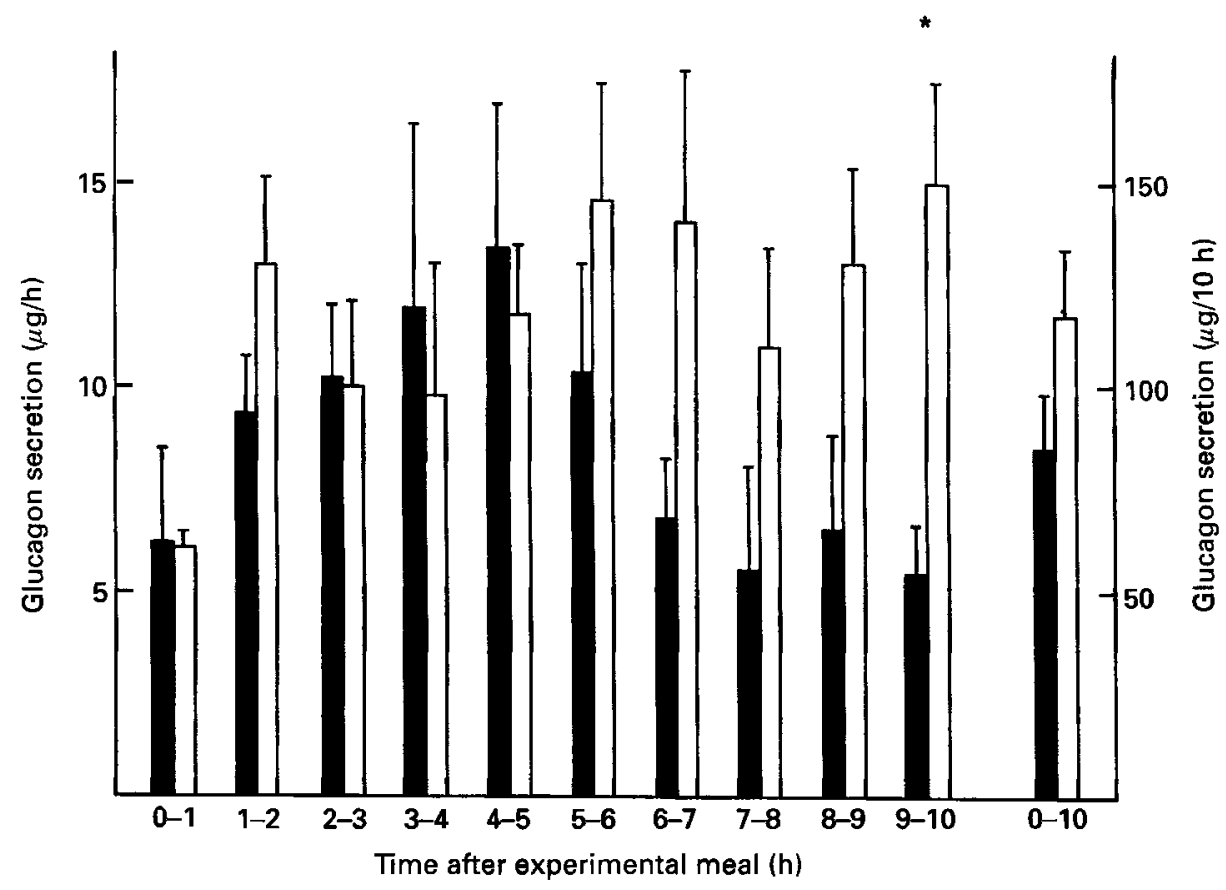

Fig. 8. Changes in the amounts of glucagon $(\mu \mathrm{g} / \mathrm{h})$ produced at various time-intervals after a meal (see Table 1) in pigs without $(C$, , or with $(D, \square)$ diversion of the exocrine pancreatic secretion. Values are means for five pigs with their standard errors represented by vertical bars. Statistical significance of the differences between treatments: ${ }^{*} P<0.05$.

the measurement of the appearance of nutrients in the portal blood, i.e. the amounts absorbed minus the amounts used in the metabolism of the intestinal wall. The apparent uptake of nutrients by the gut wall can be evaluated from the negative portal-arterial differences, i.e. during periods where the arterial blood contains more nutrients than the portal blood. This does not exclude, however, an uptake during periods of positive absorption, but it is not possible to detect it. The true uptake of nutrients by the gut wall can only be measured by the use of isotopic tracers.

The amino- $\mathrm{N}$ concentrations in blood were measured using two kinds of technique: a general technique based on the use of TNBS for analysing amino-N and an ion-exchange chromatography technique for analysing the individual amino acids. The former technique has already been criticized (Rérat et al. 1987). Its major advantages, beyond the fact that it is very simple to apply, are that it does not take into account either urea, or blood $\mathrm{NH}_{3}$ (Palmer \& Peters, 1966). Moreover, its sensitivity to amines does not constitute a disadvantage since these substances are only detected infrequently and in small amounts in blood. However, the sensitivity of the reagent to various amino acids is variable. It is $75 \%$ to basic amino acids, $50 \%$ to acid amino acids and null towards imino acids (Prenton \& London, 1967; Waring \& Bolton, 1967). The amino-N contents measured using this reagent cannot, therefore, strictly correspond to those obtained by chromatographic analysis which makes it possible to determine the $\mathbf{N}$ of each amino acid and to calculate the sum for TAA. The discrepancy between the values obtained with the two techniques depends on the composition of the diets and particularly on their basic amino acid and imino acid contents. As demonstrated elsewhere (Rérat et al. 1987), the values obtained with TNBS are lower than those obtained by chromatographic analysis. As these 
differences affect arterial and portal nutrient concentrations equally, they have little influence on the estimates of absorbed $\mathrm{N}$ which are thus relatively similar whatever the technique used.

In the presence of pancreatic secretion, absorption of glucose issuing from dietary starch and sucrose represented a hourly mean of $8.9 \%$ of the intake of the test meal over a $10 \mathrm{~h}$ period. This value, and the absorption kinetics, are similar to those found previously with a diet of similar composition (Rérat et al. 1985). In the absence of pancreatic enzymes in the digestive lumen, the hourly mean declined to $1.4 \%$; the total amount of glucose appearing in the portal blood represented only $15.5 \%$ of the amount recorded under normal physiological conditions. This depressed absorption of glucose $(86 \%)$ due to the pancreatic deprivation was much more pronounced than that observed $(20 \%$ within $8 \mathrm{~h})$ in a former experiment (Rérat et al. 1977) performed with a soyabean- and cereal-based diet. This difference may be attributed to the origin and nature of dietary starch as well as the composition of the diet. In contrast to the present data, the influence of the pancreatic deprivation on carbohydrate digestion is generally considered minor since it depresses the digestibility of purified starch in poultry by 25 points (Ariyoshi et al. 1964) and that of nonprotein energy by 5.7 points in the rabbit (Corring \& Lebas, 1977) and by 4.4 points in the pig (Corring \& Bourdon, 1977). This small increase in digestibility may be linked to the metabolism of the microflora in the hindgut lowering the faecal excretion of carbohydrate residues.

In the animals without diversion of the pancreatic secretion (Table 3), the appearance of amino-N in the portal blood (hourly: $10 \%$ of the ingested $\mathrm{N}$ ) was similar to that recorded $(9 \cdot 6 \%)$ in a former experiment performed under similar conditions (Giusi-Perier et al. 1989). The amounts of TAA absorbed within $10 \mathrm{~h}$ were higher than the intake; this can be explained by a recycling of endogenous proteins which can reach up to $2 \mathrm{~g} / \mathrm{h}$ (Rérat $e t$ al. $1988 \mathrm{c}$ ). The diversion of the pancreatic secretion resulted in a marked depression in the absorption of amino-N (52\%) and of TAA (50\%). This depression was larger than that measured (35-41\%) in pigs fed on soyabean and cereal proteins (Rérat et al. 1977). This difference may be attributed to the nature of the diets being compared. In the pig, Anderson $\&$ Ash (1971) reported a $17 \%$ depression in the $\mathrm{N}$ digestibility of diets containing 16-20\% protein, whereas Pekas et al. (1964) reported a much more marked depression due to pancreatic deprivation with soyabean proteins ( $46 \%$ depression) than with milk proteins (14\% depression). Uram et al. (1960) showed that the effect of pancreatectomy depended on the nature of the dietary proteins. These discrepancies in the effects of pancreatic deprivation according to the nature of dietary proteins are obviously related to the interaction between the specific roles of different proteolytic enzymes of the gut and the accessibility of the peptide bonds of proteins after gastric hydrolysis. In other species, pancreatectomy also led to a large depression in N digestibility: 30\% in the dog (Shingleton et al. 1955), $75 \%$ in the chicken (Ariyoshi et al. 1964), and $17-22 \%$ in the rat (Clowes \& McPherson, 1951; Uram et al. 1960). However, it should be noticed that gastric digestion and intestinal enzymes play an important role in the breakdown of carbohydrates and proteins.

As regards the kinetics of appearance of TAA and individual amino acids in the portal blood of animals without pancreatic diversion (Table 3), it was different from that observed in former experiments (Rérat et al. 1988a), the mean absorption rate within $10 \mathrm{~h}$ of some being higher (TAA, Lys, Met, Arg, His) or lower (Tyr, Pro, Cys) than that recorded previously. These differences may be attributed to the different origin of fish meal used in these experiments. Fish meal contains a variable proportion of bones, the collagen content of which has an amino acid digestibility quite different from that of muscle proteins. In the absence of pancreatic secretion the variation in the amounts of TAA and individual amino 
acids appearing in the portal blood was quite similar to that observed in the presence of pancreatic secretion, whilst the actual amounts released were reduced to about half. The flux of digesta in the small intestine, which is regulated by gastric emptying, resulted, in both cases, in an increasing amount of TAA being absorbed at least until the 4th hour, then by a gradual decrease until the 10th hour. When there was no diversion of the pancreatic secretion the kinetics of TAA absorption may be explained by the quick and great hydrolysis of residual proteins due to pancreatic enzymes, allowing a large absorption of TAA during the first hours, leaving only small amounts of amino acids offered to the absorptive surfaces during the last hours. When pancreatic secretion was diverted the kinetics of TAA absorption may be explained by the presence in the digesta coming from the stomach of molecules easily hydrolysed by the peptidases of the gut wall, i.e. oligopeptides, and of absorbable molecules, i.e. free amino acids. The gastric hydrolysis causing the release of oligopeptides and amino acids has been demonstrated by Miranda $\&$ Pelissier (1983). The extent of this hydrolysis depends on the proteins and their residence time in the stomach. It may be presumed that, for the type of diet used, this gastric hydrolysis was incomplete and resulted in the presence of large amounts of residual proteins in the intestinal lumen in addition to oligopeptides and amino acids giving rise to rather quick absorption of moderate amounts of TAA. The fact that the residual proteins were resistant to brush-border enzymes may explain the noticeable decrease of TAA absorption during the last $2 \mathrm{~h}$ of the postprandial period after deprivation.

The composition of the amino acid mixture entering the portal blood was only slightly modified by pancreatic diversion (Table 4). There were small and non-significant differences according to whether the pancreatic secretion was diverted or not and the differences varied with time. Thus, the His, Arg and Lys concentrations were higher (NS) and that of Val was slightly lower in the TAA absorbed during the first $2 \mathrm{~h}$ after diversion than in the absence of deprivation. They decreased gradually and after $10 \mathrm{~h}$ became smaller (His, $P<0.05$; Val, $P<0.06$ ) after diversion than in the absence of deprivation. By contrast, the Tyr and Thr concentrations were lower (Tyr, $P<0.05$; Thr, NS) during the first $2 \mathrm{~h}$ after diversion than in the absence of deprivation, whereas they increased further so that after $10 \mathrm{~h}$ the Thr concentration was similar and that of Tyr higher than without deprivation. These differences may be attributed to the nature and composition of the substrates hydrolysed and transported by the gut wall: oligopeptides of gastric origin in the case of diversion or products of the gastric and pancreatic breakdown in the absence of deprivation. These small qualitative differences probably have no nutritional effect.

The apparent uptake of amino acids from blood by the gut wall during the postprandial period (Table 5) reached $15.3 \mathrm{~g} / 10 \mathrm{~h}$ in the absence of deprivation and $17.9 \mathrm{~g} / 10 \mathrm{~h}$ after diversion, i.e. $16.6 \%$ and $19.4 \%$ of the amounts ingested respectively, (15.5 and $36.3 \%$ of the amounts absorbed). The uptake consisted of $76 \% \mathrm{Gln}$ and Glu in the absence of deprivation $v .71 .5 \%$ after diversion, showing the extent of the intestinal metabolism, which is similar in this case whatever the level of amino acids absorbed. This apparent uptake of TAA was lower than that recorded in previous experiments (Rérat et al. 1992) in animals infused intraduodenally with oligopeptides or free amino acid mixtures, this difference being due to the very small uptake of essential amino acids. By contrast, the intestinal metabolism induced a much higher synthesis of Ala in the absence of deprivation than after diversion. This Ala synthesis was noted in previous experiments (Rerat et al. 1992).

The blood levels of insulin paralleled those of glucose, as already observed (Rérat et al. 1985). Insulin secretion was greater when the pancreatic secretion was not diverted. These differences were significant during the first $4 \mathrm{~h}$ after the meal when the glucose absorption, which was greater in the presence of pancreatic enzymes, induced a more rapid and more 
marked increase in glycaemia than in their absence. By contrast, in the present experiment the glucagonaemia did not parallel the amino acidaemia, in contrast to what was shown in pigs given decreasing levels of dietary proteins (Rérat et al. 1985). In comparison with nondiverted animals the pancreatic diversion did not lead to any change in glucagonaemia, which probably reflects the combination of the depressive effect due to the decrease of plasma amino acid concentrations, and of the stimulatory effect due to the much greater decrease in glycaemia. Thus, the secretion of glucagon was not different under physiological conditions or when the pancreatic secretion was diverted.

In conclusion, in pigs fed on a semi-purified diet based on fish meal and maize starch, diversion of the exocrine pancreatic secretion considerably depressed $(86 \%)$ the postprandial absorption of glucose and to a lesser extent that of TAA. The composition of the mixtures of essential amino acids absorbed was only slightly modified, since at the end of the postprandial period only the His and Val concentrations were lower after diversion than under normal physiological conditions. Insulin production was lower in the animals with pancreatic deprivation because of the reduced absorption of glucose, but glucagon production was unchanged because of the joint depression of the absorption of nitrogenous nutrients and glucose. Suppressing the exocrine pancreatic secretion therefore leads to a quantitative shortage of carbohydrate and nitrogenous nutrients and not to a qualitative imbalance of these nutrients. These conclusions apply only to the specific type of diet used. However, the role played by the gastric digestion and the intestinal enzymes on the carbohydrate and protein digestion should be emphasized.

The authors would like to thank P. Vaugelade for technical assistance, G. Brachet for skilful care of animals, J. Gallé for drawings and A. Bouroche for translation of the manuscript to English.

\section{REFERENCES}

Anderson, D. M. \& Ash, R.W. (1971). The effect of ligating the pancreatic duct on digestion in the pig. Proceedings of the Nutrition Society 30, 34A-35A.

Ariyoshi, S., Koike, T., Furuta, F., Ozone, K., Matsumura, Y., Dimick, M. K., Hunter, W. L., Wang, W. \& Lopkovsky, S. (1964). The digestion of protein, fat and starch in the depancreatized chicken. Poultry Science 43, 232-238.

Clowes, G. H. A. Jr \& McPherson, L. B. (1951). Production of fatty livers by ligature of the pancreatic duct in rats. American Journal of Physiology 165, 628-638.

Corring, T., Aumaître, A. \& Rérat, A. (1972). Fistulation permanente du pancreas exocrine chez le porc. Application: réponse de la secrétion pancréatique au repas (Permanent pancreatic fistulation in the pig. Secretory response to meal ingestion.). Annales de Biologie Animale Biochimie Biophysique 12, 109-124.

Corring, T. \& Bourdon, D. (1977). Effets à long terme de la ligature du canal pancréatique sur la digestibilité apparente chez le porc (Long-term effects of pancreatic duct ligature on apparent digestibility in the pig.). Annales de Biologie Animale Biochimie Biophysique 17, 579-582.

Corring, T., Calmes, R., Rérat, A. \& Gueugneau, A. M. (1984). Effets de l'alimentation proteiprive à court terme sur la secrétion d'azote endogène: secrétion pancréatique exocrine chez le porc (Effect of short-term feeding of a protein-free diet on endogenous nitrogen secretion: exocrine pancreas secretion in the pig). Reproduction Nutrition Développement 24, 495-506.

Corring, T. \& Lebas, F. (1977). Effets à court et moyen termes de la ligature du canal pancreatique sur la digestibilité d'un aliment, chez le lapin en croissance et soumis a une alimentation restreinte (Short- and medium-term effects of pancreatic duct ligature on diet digestibility in the food-restricted growing rabbit). Annales de Biologie Animale Biochimie Biophysique 17, 299-307.

Giusi-Périer, A., Fiszlewicz, M. \& Rérat, A. (1989). Influence of diet composition on intestinal volatile fatty acid and nutrient absorption in unanaesthetized pigs. Journal of Animal Science 67, 386-402.

Henry, Y. \& Rérat, A. (1964). Variations des taux énergétiques et azotés dans l'alimentation du Porc en croissance. Observations préliminaires (Effect of levels of energy and protein on performance and carcass composition of the growing finishing pig). Annales de Biologie Animale Biochimie Biophysique 4, 263-271.

Hill, J. B. \& Kessler, G. (1961). An automated determination of glucose utilizing a glucose oxidase-peroxidase system. Journal of Laboratory and Clinical Medicine 57, 970-980. 
Juste, C., Corring, T. \& Le Coz, Y. (1983). Bile restitution procedures for studying bile secretion in fistulated pigs. Laboratory Animal Science 33, 199--202.

Métais, P. \& Bieth, J. (1968). Determination de l'alpha-amylase par une microtechnique (Determination of alphaamylase by a microtechnique). Annales Biologie Clinique 26, 133-142.

Miranda, G. \& Pélissier, J. P. (1983). Kinetic studies of in vivo digestion of bovine skim-milk proteins in the rat stomach. Journal of Dairy Research 50, 27-36.

Palmer, D. W. \& Peters, R. (1966). Kinetics of simple automatic determination of aminogroups in serum plasma using trinitrobenzene sulfonate. In Automation in Analytical Chemistry. Technicon Symposium, pp. 324-327 [L. T. Skeggs Jr, editor]. New York: Mediad Inc.

Pekas, J. C., Hays, V. W. \& Thompson, A. M. (1964). Exclusion of the exocrine pancreatic secretion. Effect on digestibility of soy bean and milk protein by baby pigs at various ages. Journal of Nutrition 82, 277-286.

Prenton, M. A. \& London, D. R. (1967). The continuous in vivo monitoring of plasma amino nitrogen. In Fifth Colloquium on Amino Acid Analysis. Technicon Monograph no. 2, pp. 70-78. Domont, France: Technicon.

Reboud, J. P., Ben Abdeljlil, A. \& Desnuelle, P. (1962). Variations de la teneur en enzymes du pancréas de rat en fonction de la composition des régimes (Changes in the concentrations of enzymes in rat pancreas according to diet composition). Biochimica et Biophysica Acta 58, 326-337.

Rérat, A. (1971). Mise au point d'une méthode quantitative d'étude de l'absorption chez le Porc (Quantitative method for studying digestive absorption in the pig). Annales de Biologie Animale Biochimie Biophysique 11, 277.

Rérat, A., Chayvialle, J. A., Kandé, J., Vaissade, P., Vaugelade, P. \& Bourrier, T. (1985). Metabolic and hormonal effects of test meals with various protein contents in pigs. Canadian Journal of Physiology and Pharmacology 63, 1547-1559.

Rérat, A., Corring, T., Vaissade, P. \& Vaugelade, P. (1977). Postprandial absorption of $\alpha$-aminonitrogen and sugars in pigs. Quantitative measurement using discontinuous pancreatic deprivation. Annales de Biologie Animale Biochimie Biophysique 17, 583-588.

Rérat, A., Jung, J. \& Kandé, J. (1988a). Absorption kinetics of dietary hydrolysis products in conscious pigs given diets with different amounts of fish protein. 2. Individual amino acids. British Journal of Nutrition 60, $105-120$.

Rérat, A., Simões Nunes, C., Mendy, F. \& Roger, L. (1988b). Amino acid absorption and production of pancreatic hormones in non-anaesthetized pigs after duodenal infusions of a milk enzymic hydrolysate or of free amino acids. British Journal of Nutrition 60, 121-136.

Rérat, A., Simoes Nunes, C, Mendy, F., Vaissade, P. \& Vaugelade, P. (1992). Splanchnic fluxes of amino acids after duodenal infusion of carbohydrate solutions containing free amino acids or oligopeptides in the nonanaesthetized pig. British Journal of Nutrition 68, 111-138.

Rérat, A., Simões Nunes, C., Vaissade, P. \& Roger, L. (1987). Comparaison de deux techniques d'estimation (ninhydrine vs TNBS) de l'azote des acides aminés circulants appliquées à l'étude de l'absorption intestinale de solutions d'acides aminés libres et de petits peptides (A comparison of two techniques (ninhydrin vs TNBS) for estimating circulating amino acid nitrogen: application to the study of absorption of solutions of free amino acids or small peptides in the intestine). Reproduction Nutrition Développement 27, 955-966.

Rérat, A., Vaissade, P. \& Vaugelade, P. (1988c). Quantitative measurement of endogenous amino acid absorption in unanaesthetized pigs. Archives of Animal Nutrition 38, 463-479.

Rérat, A. \& Vaugelade, P. (1983). Debitmétrie chronique de la veine porte chez le porc. (Chronic portal bloodflow measurement in the pig). Sciences et Techniques des Animaux de Laboratoire 8, 239-248.

Rérat, A., Vaugelade, P. \& Villiers, P. (1980). A new method for measuring the absorption of nutrients in the pigs: critical examination. In Current Concepts on Digestion and Absorption in Pigs, pp. 177-216 [A. G. Low and I. G. Partridge, editors]. Reading: National Institute for Research in Dairying.

Shingleton, W. W., Wells, M. H., Baylin, G. H., Ruffin, J. M., Saunders, A. \& Durham, N. C. (1955). The use of radioactive labelled protein and fat in the evaluation of pancreatic disorders. Surgery 38, $134-142$.

Snedecor, G. W. \& Cochran, W. G. (1967). Statistical Methods. Ames, IA: Iowa State University Press.

Uram, J. A., Friedman, L. \& Kline, O. L. (1960). Relation of pancreatic exocrine to nutrition of the rat. American Journal of Physiology 199, 387-394.

Waring, J. J. \& Bolton, W. (1967). 2-4-6-trinitrobenzene sulfonic acid as a colour reagent for amino acid analysis. In Fifth Colloquium on Amino Acid Analysis. Technicon Monograph no. 2, pp. 30-34. Domont, France: Technicon. 